\title{
PARADIGMA ZIARAH DALAM PENAFSIRAN ALKITAB
}

\author{
Demianus Nataniel \\ Sekolah Tinggi Theologia Abdiel \\ demianusnataniel@gmail.com
}

\begin{abstract}
One of the critical problems in hermeneutic praxis is the tendency of emphasizing one part in a hermeneutical circle, namely context, text, or reader. Therefore we should take into account the whole part in an interdependence balance. Instead of emphasizing one of the part in the hermeneutic circle, this paper offers pilgrimage as a paradigm in interpreting the Bible so that the whole part in a hermeneutical circle can be put in an interdependence balance. The use of pilgrimage as a paradigm in the interpretation of the Bible should be understood as Groome has been doing by taking pilgrimage as a paradigm in his Shared Christian Praxis approach.
\end{abstract}

Keywords: Hermeneutic, Interpreting the Bible, Paradigm, Pilgrimage, and Shared Christian Praxis.

\section{Pendahuluan}

Istilah ziarah sudah cukup banyak dipakai oleh teolog-teolog Kristen untuk menyampaikan pemikiran-pemikirannya. Beberapa teolog bahkan menggunakan ziarah sebagai salah satu kata kunci dalam pemikiran teologisnya. Seorang di antaranya adalah Thomas H. Groome. ${ }^{1}$ Dalam pendekatan Shared Christian Praxis, Groome mengangkat istilah ziarah untuk menjelaskan kehadiran gereja dalam tiga dimensi waktu yang saling terkait dalam proses pendidikan. ${ }^{2}$ Walaupun Groome tidak panjang dan lebar menjabarkan istilah ziarah, tetapi istilah ini dapat dikatakan menjiwai seluruh proses dalam pendekatan tersebut. Ziarah dapat dikatakan sebagai paradigma atau kerangka berpikir dalam pendekatan yang ditawarkannya. Dengan cara yang hampir sama dengan yang dilakukan oleh Groome tatkala memanfaatkan ziarah dalam pendekatan Shared Christian Praxis,

\footnotetext{
${ }^{1}$ Selain Thomas H. Groome, Amos Yong juga menggunakan istilah pilgrim untuk menjelaskan hospitalitas gereja dalam perjumpaan dengan umat beragama lain. Amos Yong, Hospitality and the Other. (New York: Orbis Books, 2008), 156. Selain itu ada juga Joy Ann McDougall yang mengurai pemikiran Trinitarian Moltmann dengan menggunakan istilah Pilgrimage of Love. Joy Ann McDougall, Pilgrimage of Love. (Oxford: University Press, 2005). Di bidang biblika ada juga Baverly R. Gaventa dan Richard B. Hays yang menggunakan istilah pilgrimage dalam menggambarkan upaya pencarian bersama identitas Yesus. Gaventa, Baverly R., \& Richard B. Hays, peny.,Seeking Identity of Jesus: A Pilgrimage. (Grand Rapids,MI: Wm. B. Eerdmans, 2008).

${ }^{2}$ Thomas H. Groome, Christian Religious Education. (San Fransisco: Harper \& Row, 1980), 12-17.
} 
makalah ini mengulas bagaimana ziarah dipakai sebagai sebuah paradigma dalam menjelaskan proses penafsiran Alkitab yang seharusnya dilakukan oleh gereja. Penafsiran Alkitab seharusnya merupakan peziarahan gereja saat ini, sebagai pembaca, yang dengan sadar dan sengaja ingin mengalami perjumpaan dengan Allah melalui teks Alkitab dan para penulisnya.

\section{Lingkaran Hermeneutik}

Dalam penafsiran sebuah teks, termasuk Alkitab, selalu ada tiga pihak yang terlibat, yakni penulis, pembaca dan teks itu sendiri. Ketiga pihak ini berada dalam lingkaran hermeneutik yang merupakan proses perjumpaan dan komunikasi antara pembaca yang senantiasa memiliki prapaham atau bisa juga berupa prasangka, dengan teks yang tengah dibaca dan dipahami, termasuk dengan penulis ataupun redaktor yang menghasilkan teks dalam bentuknya yang terakhir. Oleh sebab itu model-model atau pendekatan dalam penafsiran Alkitab tentunya memahami dan menyadari keterlibatan ketiga pihak dalam lingkaran hermeneutik tersebut. Walaupun secara umum model-model penafsiran Alkitab yang ada menyadari keterlibatan pembaca, penulis dan teks dalam lingkaran hermeneutik, tetapi beberapa pendekatan yang relatif menonjol dalam sejarah penafsiran Alkitab, seperti kritik sejarah, kritik literer, dan kritik pembaca, tampaknya lebih menekankan satu di antaranya. ${ }^{3}$

Sebelum zaman pencerahan, penafsiran Alkitab tampaknya dilakukan sebagai bagian dari usaha untuk menjelaskan atau mempertahankan pemahaman dogmatis yang diusung oleh para penafsir. ${ }^{4}$ Dalam hal ini pemahaman yang ada dalam diri para penafsir atau pembaca teks Alkitab dipandang sebagai yang paling dominan. Pergeseran terjadi di era modern ketika rasionalitas menjadi patokan dalam menilai segala sesuatu termasuk tradisi iman Kristen. Kisah-kisah yang ada dalam Alkitab dipertanyakan kebenarannya berdasarkan standar rasionalitas, yang pada gilirannya mengarahkan para penafsir untuk mencari latar belakang penulisan teks-teks dalam Alkitab.

Pendekatan kritik sejarah adalah bentuk modernisasi dalam praktek penafsiran Alkitab. $^{5}$ Dalam pendekatan ini maksud dari pengarang teks-teks Alkitab beserta

\footnotetext{
${ }^{3}$ Bdk. Anderson, Janice C. \& Stephen D. Moore, "Introduction: The Lives of Mark", in Marks \& Method: New Approaches in Biblical Studies, peny. Janice C. Anderson \& Stephen D. Moore. (Minneapolis: Fortress Press, 1992), 1-22.

${ }^{4}$ Bdk. William Yarchin, History of Biblical Interpretation: A Reader (Peabody, Massachusetts: Hendrickson Publishers, Inc.), xvii-xxii.

${ }^{5}$ Ibid., 195-197.
} 
konteksnya menempati tempat utama. Begitu asyiknya para penafsir yang menekankan peran penulis dibalik teks-teks yang ditafsirkan sehingga banyak kalangan melihat bahwa itu semua berakhir tanpa mempedulikan apakah bermanfaat bagi pertumbuhan iman umat atau tidak. ${ }^{6}$ Dengan kata lain pendekatan ini akhirnya dirasakan kering karena ketiadaan makna terkait konteks masa kini. Lebih dari itu, kegelisahan muncul terkait dengan kewibawaan normatif Alkitab yang seolah-olah tidak dihargai sama sekali sebagai kitab suci, antara lain dengan mencincang teks-teks Alkitab hanya untuk menemukan sesuatu yang ada di balik teks-teks itu.

Situasi sebagaimana tersebut di atas mendorong terjadinya pergeseran ke arah yang lebih menempatkan teks di tempat yang utama. ${ }^{7}$ Kegelisahan terkait turunnya kewibawaan Alkitab sebagai kitab suci mendorong upaya untuk mengembalikan Alkitab kembali ke tempat yang berwibawa. Alkitab harus diterima sebagaikanon kitab suci dalam bentuknya yang terakhir. Penelusuran latar belakang penulisan teks-teks Alkitab dianggap hanya membuang-buang waktu dan tidak memiliki manfaat berarti bagi pertumbuhan iman gereja. Kritik narasi adalah bagian dari pendekatan yang lebih menekankan teks, walaupun sebelumnya kritik bentuk juga sudah memulainya sebagai sebuah pendekatan transisi dari yang menekankan penulis kepada yang lebih menekankan teks.

Jika dicermati pendekatan-pendekatan yang menekankan baik penulis maupun teks dalam proses penafsiran, tampaknya keduanya sama-sama memahami bahwa pesan yang hendak diraih dari proses penafsiran itu berada dalam teks itu sendiri. Seolah-olah hanya di dalam teks itulah pesan-pesan yang hendak diraih hadir dan tersembunyi. Inilah yang kemudian mendorong munculnya pendekatan yang lebih menekankan peran pembaca dalam proses penafsiran. Kritik pembaca, termasuk di dalamnya tafsir feminis dan tafsir yang didasarkan teologi pembebasan, adalah contoh model penafsiran yang memahami bahwa para pembacalah yang menentukan makna dari teks yang ditafsirkan. ${ }^{8}$

Dari semua pergeseran yang terjadi dalam sejarah penafsiran Alkitab tampak jelas bahwa ketiga pihak dalam lingkaran hermeneutik memiliki peran yang sangat penting dan tidak boleh satu pun yang diabaikan. Kegelisahan-kegelisahan yang kemudian mendorong terjadinya pergeseran penekanan pihak-pihak dalam lingkaran hermeneutik membuktikan

\footnotetext{
${ }^{6}$ Bdk. Komisi Kitab Suci dan Kepausan, Penafsiran Alkitab Dalam Gereja, terj. V. Indra Sanjaya Pr. (Yogyakarta: Kanisius, 2003),

${ }^{7}$ Bdk. Emannuel Gerrit Singgih, “Apa dan Mengapa Exegese Naratif?”, GEMA:Exegese Narasi dalam Teori dan Praktek, No. 46 (Yogyakarta: F.Th UKDW, 1993), 5-26.

${ }^{8}$ Bdk. Robert M. Fowler, "Reader-Response Criticism: Figuring Mark’s Reader", dalam Mark \& Method: New Approaches in Biblical Studies, peny. Janice C. Anderson \& Stephen D. Moore (Minneapolis: Fortress Press, 1993), 50-83.
} 
bahwa ketika ada pihak yang diabaikan maka akan menimbulkan persoalan. Ketika penafsiran Alkitab bertumpu pada pencarian hal-hal yang terkait dengan penulisan teks Alkitab maka pertanyaannya lebih kepada makna atau relevansinya bagi pergumulan gereja saat ini.

Tatkala penafsiran Alkitab hanya memfokuskan diri pada teks dalam bentuknya yang terakhir maka bukankah itu berarti menutup mata bahwa teks Alkitab berasal dari dunia masa lalu yang jelas-jelas berbeda dengan dunia saat ini? Lalu bagaimana dengan penafsiran yang lebih menekankan peran pembaca, termasuk pergumulan kontekstual lingkungannya? Pendekatan ini memang memiliki sisi positif terutama berkaitan dengan makna atau relevansi penafsiran itu bagi konteks masa kini, tetapi jika hanya pergumulan masa kini yang hendak dijawab maka berbagai jawaban bisa diraih melalui sumber-sumber yang ada tanpa harus melalui Alkitab. Artinya, ketika proses pencarian jawab atas pergumulan-pergumulan masa kini diraih melalui penafsiran Alkitab maka suka atau tidak, fakta bahwa Alkitab adalah teks dari masa lalu tidak boleh diabaikan begitu saja.

Kalau persoalannya sebagaimana diuraikan di atas maka apakah itu berarti perlu ada pendekatan baru yang lebih menghargai semua pihak yang terlibat dalam proses penafsiran Alkitab? Jawabannya bisa ya, tetapi jugabisa tidak karena yang terpenting dari semuanya adalah paradigma atau kerangka berpikir yang harus dimiliki oleh gereja saat menafsirkan Alkitab. Ziarah tampaknya layak untuk dijadikan sebagai sebuah paradigma dalam penafsiran Alkitab untuk turut menyelesaikan perdebatan siapa yang paling menentukan dari ketiga pihak yang terlibat dalam lingkaran hermeneutik.

\section{Ziarah dalam Tradisi Agama-agama}

Ziarah atau pilgrimage adalah istilah yang cukup dikenal dalam agama-agama, seperti Islam, Kristen, Hindu, Budha, dan yang lainnya. Ziarah secara sederhana dapat dipahami sebagai perjalanan mengunjungi tempat-tempat yang dianggap suci atau keramat dalam rangka memperdalam penghayatan hubungan dengan yang illahi. ${ }^{9}$ Peziarahan selalu berhubungan dengan sebuah komunitas. Tidak ada tempat peziarahan yang hanya dimiliki dan dinikmati oleh seseorang. Situs-situs peziarahan biasanya dibangun dan dipelihara oleh sebuah komunitas tertentu.

Di kalangan Kristen, istilah ziarah biasa digunakan untuk menggambarkan perjalanan gereja dalam menunaikan tugas panggilannya selaku musafir di dunia ini.

${ }^{9}$ Eliade, M., The Encyclopedia of Religion, Vol 11 (New York: Macmillan, 1987), 328-330. 
Dalam tradisi Kristen, tempat-tempat yang dianggap suci atau keramat adalah tempattempat yang diyakini pernah terjadi peristiwa luar biasa sebagaimana dikisahkan dalam Alkitab. Selain itu ada juga orang Kristen yang melakukan ziarah dengan mengunjungi makam orang-orang yangdianggap suci. ${ }^{10}$ Mereka yang terlibat dalam peziarahan mengenang dan menghayati peristiwa-peristiwa yang pernah terjadi di masa lalu sekaligus orang-orang yang terlibat dalam persitiwa-peristiwa tersebut. Para peziarah itu pada gilirannya juga meneladani orang-orang yang dikenang, yang terkait dengan peristiwa di tempat yang dikunjungi.

Dalam perjalanan ziarah, para peziarah senantiasa harus menyadari dan menghargai keberadaan orang lain yang juga sama-sama berziarah. Mereka bermitra dan berkomunikasi agar peziarahan berjalan dengan lancar dan dapat dinikmati. Walaupun mungkin saja di antara mereka tidak mengeluarkan kata-kata, tetapi setidaknya masingmasing akan memperhatikan bagaimana yang lain bergerak. Pergerakan mereka tidak hanya mengikuti keinginan hati sendiri. Pergerakan seseorang akan menjadi tanda bagi pergerakan yang lainnya. Adakalanya pergerakan mereka diatur oleh sebuah ritus yang harus mereka ketahui dan patuhi bersama. Jika ada peziarah yang hanya memperhatikan dirinya sendiri maka akan mengganggu peziarah lainnya, bahkan kemungkinan bisa terjadi kekacauan dan bencana. Jika hanya memperhatikan kepentingan diri sendiri maka bisa jadi mereka akan berebut tempat dan saling menyingkirkan satu sama lain. Berbagai peristiwa tragis pernah terjadi ketika para peziarah mengabaikan keberadaan orang lain dalam peziarahan. Sebagai contoh adalah tragedi Mina yang menewaskan 1.426 orang jemaah haji akibat saling injak di terowongan Haratul Lisan, Mina. ${ }^{11}$

Dalam perjalanan ziarah juga terkandung pemahaman bahwa manusia berada dalam tiga dimensi waktu yang saling berkaitan, yakni masa lalu, masa kini dan masa yang akan datang. Ziarah berkaitan dengan sesuatu yang terjadi di masa lalu karena para musafir senantiasa berusaha untuk mengingat, menghayati dan menikmati sesuatu yang pernah terjadi di masa lalu. Ziarah juga terkait dengan masa kini karena dilakukan dan dijalankan oleh para peziarah sekarang. Akhirnya, ziarah juga berkaitan dengan masa depan. Dilakukan oleh peziarah bukan hanya untuk kehidupan saat ini tetapi juga untuk kehidupannya di masa depan.

\footnotetext{
${ }^{10}$ Sabine MacCormack, "Loca Sancta: The Organization of Sacred Topography in Late Antiquity", dalam Blessings of Pilgrimage, peny. Robert Ousterhout ( Urbana and Chicago: University of Illinois Press, 1990), 8.

${ }^{11}$ Dekade 80,’Tragedi Mina", http://www.dekade80.blogspot.com/2008/12/tragedi-mina.html. Diakses 28 April 2012.
} 
Hal lain yang juga penting untuk dicermati dalam perjalanan ziarah adalah adanya kerinduan para peziarah untuk dalam waktu bersamaan menikmati hal-hal yang ilahi dan insani, yang sorgawi dan duniawi. Mereka berusaha bukan hanya menikmati keindahankeindahan fisik tempat-tempat peziarahan, tetapi juga kekuatan-kekuatan illahi yang diyakini berada di belakangnya. Ziarah juga senantiasa bersifat dinamis dan terbuka karena para peziarah tidak pernah berniat untuk tinggal di tempat yang dikunjungi. Mereka hanya singgah dan kemudian melanjutkan peziarahan hingga akhir hayat.

\section{Paradigma Ziarah dalam Pendekatan Shared Christian Praxis}

Dengan menggunakan ziarah sebagai sebuah paradigma, setidaknya ada empat hal yang ingin disampaikan oleh Groome melalui pendekatan Shared Christian Praxis. Pertama, selain dilakukan secara sadar, terarah dan terencana, paradigma ziarah menegaskan pendidikan harus memiliki tujuan yang jelas. Groome sepakat dengan pemikiran yang memahami bahwa pendidikan sejatinya bersifat politis, yakni mengarahkan masyarakat untuk menjadi warga negara sesuai ideologi yang mendasarinya. $^{12}$ Pendidikan Kristiani dalam hal ini secara tegas dilakukan untuk mengarahkan umat agar terlibat dalam mendukung terciptanya tanda-tanda Kerajaan Allah. ${ }^{13}$

Kedua, orang-orang yang terlibat dalam proses pendidikan menempatkan diri sebagai para musafir. Konsekuensinya, guru dan murid berada dalam relasi kemitraan yang bersifat dialogis, saling melengkapi dan membebaskan. Murid tidak dianggap sebagai orang yang harus menerima informasi saja, dan guru tidak dipandang sebagai orang yang serba tahu. Murid dihargai sebagai orang yang memiliki pribadi sendiri dan dipandang telah memiliki pengetahuan atau pemahaman tertentu yang layak diperhitungkan. Baik guru maupun murid pada gilirannya sama-sama orang yang belajar. Guru dapat dikatakan sebagai seorang yang membimbing sekaligus belajar. Namun demikian mereka menyadari fungsinya masing-masing, betapapun sama-sama sebagai orang yang belajar, para guru atau pendamping dihormati dan diakui memiliki peran memberikan petunjuk dan arahan agar semua yang terlibat berjalan tertib dan teratur, serta meraih tujuan yang diinginkan bersama.

\footnotetext{
${ }^{12}$ Thomas H. Groome, "Christian Education for Freedom: A Shared Praxis Approach", dalam Foundation of Religious Education, peny. Padraic O’Hare (New York: Paulist Press, 1978), 1.

${ }^{13}$ Dalam Christian Religious Education disebut Kingdom of God, tetapi karena telah banyak dikritik oleh kaum feminis maka dalam Sharing Faith istilahnya diganti menjadi Reign of God.Lih.Thomas H. Groome, Sharing Faith (San Fransisco: Harper \& Row, 1991), 453.
} 
Ketiga, pertentangan antara pendidikan kristiani yang berpusat pada isi (tradisi gereja) dengan pendidikan yang berpusat pada manusia (pengalaman atau kehidupan nyata) diperdamaikan. Paradigma ziarah menjadikan pendidikan kristiani menghargai secara utuh baik tradisi gereja maupun pengalaman atau kehidupan nyata para pelakunya. Tradisi gereja didialogkan dengan pengalaman serta kehidupan nyata para murid melalui suatu refleksi kritis. ${ }^{14}$ Dengan demikian pendidikan kristiani tidak hanya bertujuan mewariskan tradisi gereja tetapi juga melengkapi kebutuhan para pelaku pendidikan dalam menghadapi tantangan zaman.

Keempat, kemitraan yang dibangun dalam proses pendidikan, serta penghargaan secara utuh terhadap pengalaman dan tradisi gereja menjadikan para pelaku pendidikan memiliki sikap terbuka terhadap perbedaan sekaligus kesetiaan kepada tradisi imannya. Pendidikan yang demikian pada gilirannya akan menghargai perbedaan keyakinan tanpa khawatir terancam oleh kehadiran orang lain.

\section{Paradigma Ziarah dan Hermeneutika Kekaguman}

Dengan menggunakan ziarah sebagai sebuah paradigma maka pertama kali yang harus dipahami adalah bahwa penafsiran Alkitab harus menghargai ketiga pihak dalam lingkaran hermeneutik. Penafsiran Alkitab adalah peziarahan gereja dalam tiga dimensi waktu yang saling terkait. Dalam proses penafsiran Alkitab, gereja secara sadar tengah berhubungan dengan dokumen-dokumen yang dihasilkan oleh orang beriman di masa lalu, termasuk gereja-gereja perdana, yang memiliki latar belakang khas, yang berbeda dengan apa yang ada pada saat ini. Dokumen-dokumen tersebut memuat pandangan-pandangan teologis orang beriman di masa lalu yang tengah bergumul sesuai dengan konteksnya. Namun demikian dokumen-dokumen tersebut dibaca oleh gereja saat ini. Jurang perbedaan konteks orang beriman di masa lalu dan gereja pada masa kini harus disadari. Kewaspadaan terhadap bahaya eisegese dan anakronisme tetap relevan untuk dimiliki, walaupun harus disadari pula adanya teks-teks anakronistik dalam Alkitab itu sendiri. Penggunaan ilmu-ilmu sosial pada akhirnya tetap bermanfaat dalam mengurai dan merekonstruksi pandangan-pandangan teologis orang beriman di masa lalu, termasuk gereja-gereja perdana. Dengan demikian pendekatan-pendekatan yang menekankan latar belakang penulisan teks-teks Alkitab tetap penting dan bermanfaat.

\footnotetext{
${ }^{14}$ Bdk. James E. Plueddermann, 'Do We Teach The Bible or Do We Teach Students?', dalam Christian Journal of Education, Vol. X, no 1 (Illinnois: Scripture Press Ministries, 1989), 78.
} 
Lalu bagaimana dengan gugatan atau yang mempersoalkan manfaat upaya rekonstruksi pandangan teologis gereja-gereja perdana? Ketika gereja dengan sadar menggunakan Alkitab sebagai dokumen yang hendak dipahami maka gereja juga seharusnya menyadari bahwa apa yang dilakukannya adalah dalam rangka belajar memahami bagaimana gereja perdana berteologi, bagaimana Allah berfirman dan berkarya di tengah masyarakat tertentu di masa lalu. Artinya, melalui proses penafsiran teks-teks Alkitab, gereja secara sadar hendak mendapatkan suatu pelajaran berharga dari masa lalu dalam rangka kehidupan saat ini dan di masa yang akan datang. Dalam hal ini, tiga dimensi waktu yang terkandung dalam paradigma ziarah sesungguhnya tidak hanya berkaitan dengan proses penafsiran yang melibatkan tiga pihak dalam lingkaran hermeneutik saja, tetapi juga mendasari pemikiran mengenai gereja sebagai pembaca Alkitab. Gereja yang ada saat ini adalah gereja sebagai hasil proses perjalanan panjang orang beriman sejak zaman rasuli, bahkan sejak zaman Perjanjian Lama. Di sisi lain, mengingat Alkitab adalah produk teologis gereja-gereja perdana di masa lalu maka penafsiran Alkitab dapat juga dipahami sebagai sebuah upaya gereja dalam berteologi untuk mengenal jati dirinya. Dengan kata lain gugatan yang mempersoalkan manfaat rekonstruksi gereja-gereja perdana berdasarkan teks-teks Alkitab adalah sebuah gugatan yang tidak berdasar. Gugatan tersebut bagaikan seorang yang mempersoalkan seorang dewasa yang sedang mencari tahu asal usulnya agar bisa bertindak sesuai dengan jati dirinya.

Dalam kaitannya dengan proses penafsiran Alkitab saat ini, setidaknya ada pejabatpejabat gereja, para teolog dan anggota jemaat biasa yang terlibat bersama-sama. Dengan menggunakan paradigma ziarah maka dalam proses penafsiran Alkitab semua unsur dalam gereja itu sama-sama bertindak sebagai musafir atau peziarah. Sebagai peziarah mereka harus saling menghargai kelebihan dan kekurangan satu sama lain serta harus bekerja sama dengan saling mendengarkan. Memberi tempat dan peran sesuai dengan kemampuannya. Dengan demikian penafsiran Alkitab harus dipahami sebagai sebuah kegiatan gereja yang melibatkan semua unsur dalam persekutuan, dan untuk kepentingan persekutuan.

Penafsiran Alkitab tidak hanya dikuasai atau hanya dinikmati oleh para pejabat gereja atau teolog saja, tetapi juga bersama dengan seluruh anggota jemaat. Dengan demikian penafsiran Alkitab tidak bisa dilakukan sebagai keasyikan para teologtanpa mempedulikanakibat dan manfaatnya bagi pertumbuhan iman gereja. Kita tidak bolehmencincang teks-teks Alkitab tanpa meraciknya kembali menjadi adonan yang siap dimasak oleh gereja, dan kemudian dihidangkan sebagai makanan lezat dan menyehatkan bagi pertumbuhan iman warga gereja. Di sisi lain, warga gereja juga harus menyadari akan 
segala keterbatasan yang dimilikinya. Mereka perlu menghargai kemampuan dan peran teolog dalam mendampingi mereka untuk dapat menafsirkan Alkitab. Mereka harus mendengarkan pandangan-pandangan para teolog agar peziarahan mereka sampai pada tujuan yang diharapkan.

Lalu bagaimana dengan para pejabat gereja? Peran mereka dalam peziarahan gereja melalui penafsiran Alkitab sangat penting. Para pejabat gereja bisa terdiri dari para teolog tetapi bisa juga anggota jemaat biasa. Tugas utama mereka adalah mengawal perputaran roda organisasi gereja sebagai sebuah institusi. Di tangan merekalah rumusan visi dan misi gereja dirumuskan secara formal. Mengingat peran strategis para pejabat gereja dalam menentukan kebijakan-kebijakan resmi gereja maka penting bagi mereka terlibat dalam kemitraan dengan para penafsir lainnya dalam memaknai teks-teks Alkitab. Sehingga perumusan visi dan misi, serta seluruh kebijakan-kebijakan gerejawi dijiwai oleh pemahaman bersama gereja dalam mengekspresikan jati dirinya sesuai pesan yang terkandung dalam Alkitab. Sebaliknya, dalam proses penafsiran, kebijakan-kebijakan formal yang dibuat oleh para pejabat gereja harus diperhatikan dan dipertimbangkan.

Jika penafsiran Alkitab harus dilakukan dalam konteks persekutuan maka apakah berarti tidak ada ruang bagi kepentingan pribadi? Ruang bagi kepentingan pribadi dengan menafsirkan Alkitab tidak pernah dapat dibatasi apalagi ditutup. Setiap orang, siapapun dia, berhak membaca dan menikmati Alkitab. Justru dalam konteks persekutuan maka kepentingan pribadi pembaca Alkitab dapat diekspresikan secara terbuka dan bahkan diperkaya. Dalam hal ini penting untuk menyimak pandangan dari Robert Mulholland yang memahami peziarahan sebagai panggilan bagi setiap orang Kristen untuk mengembangkan spirtualitasnya. Dia mengatakan bahwa spiritualitas kelompok dan spiritualitas sosial adalah dua elemen yang tidak dapat dipisahkan dalam perjalanan iman kita menuju keutuhan. ${ }^{15}$ Dengan kata lain pertumbuhan iman pribadi mendapat tempatnya yang sah dalam komunitas, baik di tengah persekutuan orang percaya maupun di tengah masyarakat yang lebih luas.

Pertanyaan lain yang tidak kalah penting adalah berkaitan dengan titik berangkat proses penafsiran Alkitab. Apakah penafsiran Alkitab dimulai dengan rekontruksi masa lalu? Tidak! Sebuah peziarahan harus dimulai dari kondisi saat ini. Gereja harus merumuskan terlebih dahulu persoalan yang menjadi keprihatinannya saat ini. Berdasarkan

\footnotetext{
${ }^{15}$ M. Robert Mulholland, Panggilan Ziarah: Bagaimana Mengembangkan Spiritualitas yang
} Holistik, terj. R. Herutomo. (Yogyakarta: Yayasan Andi, 2002), 183. 
kondisi nyata saat ini maka gereja kemudian merumuskan harapan-harapannya. Apa yang diinginkannya di masa depan. Artinya, gereja dengan sadar pula mengharapkan terjadinya perubahan. Berdasarkan kondisi saat ini serta perubahan-perubahan bagi terciptanya kondisi yang diharapkan di masa depan maka penggalian makna teks Alkitab termasuk rekonstruksi pemikiran teologis gereja-gereja perdana dilakukan. Dengan demikian, penafsiran Alkitab tidak lain adalah bagian dari upaya gereja dalam mendorong terjadinya perubahan.

Harapan gereja dengan perubahan yang diinginkan tentunya harus didasarkan pada suatu gagasan ideal yang jelas. Gereja harus menentukan terlebih dahulu gagasan ideal itu. Sejalan dengan pemikiran Groome dalam pendekatan Shared Christian Praxis maka gagasan ideal itu adalah kondisi-kondisi yang sesuai dengan tanda-tanda Kerajaan Allah. Keadilan, perdamaian, kesetaraan dalam relasi laki-laki dan perempuan, serta keutuhan ciptaan adalah contoh kondisi-kondisi umum dari tanda-tanda Kerajaan Allah yang dapat lebih dikhususkan oleh gereja sesuai dengan konteksnya masing-masing. Dan penafsiran Alkitab adalah upaya gereja yang dengan sadar hendak meraih kondisi-kondisi sesuai dengan tanda-tanda Kerajaan Allah sebagaimana dijelaskan di atas.

Berdasarkan harapan terjadinya perubahan inilah maka peziarahan gereja melalui penafsiran Alkitab mulai dilaksanakan. Peran para teolog di sini menjadi sangat berarti. Berdasarkan kemampuannya mereka mendampingi warga jemaat menelusuri teks-teks Alkitab yang relevan. Pemahaman-pemahaman awal yang dimiliki oleh warga jemaat terkait dengan teks Alkitab dan relevansinya didialogkan dengan hasil penafsiran ilmiah yang juga memanfaatkan hasil-hasil penafsiran gereja-gereja sebelumnya. Keterampilan para teolog berkomunikasi dalam peziarahan itu menjadi kunci bukan hanya membuka cakrawala atau pemahaman bersama yang lebih luas mengenai teks Alkitab dan relevansinya, tetapi juga kenyamanan umat dalam melakukannya. Untuk itu hermeneutika yang dibangun dalam peziarahan ini adalah hermeneutika kekaguman dan bukan hermeneutika kecurigaan. ${ }^{16}$

Hermeneutika kekaguman adalah hermenutika yang meyakini bahwa Alkitab adalah dokumen yang menyediakan tempat bagi gereja saat ini untuk merasakan perjumpaan dengan Allah bersama dengan gereja-gereja perdana, sehingga mengundang

\footnotetext{
${ }^{16}$ Bandingkan hermeneutika kecurigaan sebagaimana yang dianut oleh Fiorenza yang memahaminya sebagai sebuah upaya menggali visi-visi dan nilai-nilai baik yang membebaskan maupun yang menindas, yang terkandung dalam teks Alkitab dengan mengidentifikasi dinamika dan karakter patriakhal dalam teks tersebut dan penafsiran-penafsirannya. Elisabeth S. Fiorenza, But She Said: Feminist Practices of Biblical Interpretation (Boston, Massachusetts: Beacon Press, 1992), 57.
} 
gereja saat ini untuk menelusuri dengan penuh gairah dan hormat setiap pergumulan gereja di masa lalu bersama Allah yang hidup. Dalam hermeneutika kekaguman maka fokus utama adalah pencarian akan firman dari Allah yang mengagumkan itu. Rekonstruksi pandangan-pandangan teologis orang beriman di masa lalu, termasuk gereja-gereja perdana bukan semata-mata untuk menemukan titik-titik persoalan yang terserap dalam teks-teks Alkitab yang pada gilirannya juga dicurigai menjadi akar persoalan kehidupan saat ini, tetapi lebih pada bagaimana merasakan kehadiran Allah dalam keterbatasan-keterbatasan gereja perdana saat merumuskan pandangan-pandangan teologisnya. Para peziarah selalu memandang positif unsur-unsur insani karena meyakininya sebagai yang mengandung kekuatan-kekuatan ilahi. Demikian pula seharusnya dalam penafsiran Alkitab. Di balik pergumulan-pergumulan manusiawi sebagaimana tercermin dalam teks-teks Alkitab terkandung kehadiran Allah yang menguatkan.

Hermeneutika kekaguman secara praktis sesungguhnya bukan hal yang baru. Hal ini sudah dilakukan oleh para bapa gereja, bahkan diteruskan oleh para reformator, khususnya Luther dan Calvin. Dalam bukunya yang berjudul Recovering Theological Hermeneutics, Zimmerman menilai bahwa upaya para bapa gereja dan para reformator yang hadir sebelum pencerahan tidak lain adalah bentuk usaha mereka untuk mengenal Allah dengan baik dan benar. Zimmermann merumuskan usaha para bapa gereja dan para reformator, khususnya Luther dan Calvin, sebagai upaya bersekutu dengan Allah (communion with God). ${ }^{17}$ Bagi Zimmermann hermeneutika adalah upaya untuk mengenal diri dan pengenalan diri hanya dapat dilakukan ketika manusia mengenal Allah. Pemahaman ini sejalan dengan prinsip Augustinus dan Anselmus, yakni iman yang berusaha memperoleh pengetahuan (fides quaerens intellectum/ faith seeking understanding). ${ }^{18}$

Hal terakhir yang perlu diperhatikan adalah penggunaan paradigma ziarah dalam penafsiran Alkitab selalu bersifat dinamis dan terbuka. Penafsiran Alkitab dapat dipahami sebagai sebuah persinggahan. Sebagai tempat persinggahan maka hasil penafsiran Alkitab tidak dapat dipegang sebagai kebenaran tanpa batas waktu. Makna peziarahan hari ini terhadap teks yang sama bisa berbeda hasilnya dengan peziarahan yang dilakukan di tempat lain sebelumnya atau pada masa yang akan datang. Semuanya bergantung kepada konteks gereja yang melakukan peziarahan tersebut. Salah satu contoh perubahan proses

\footnotetext{
${ }^{17}$ Lih. Jens Zimmermann, Recovering Theological Hermenutics: An Incarnational-Trinitarian Theory of Interpretation (Grand Rapids, Michigan: Baker Academic, 2004), 17-47.

${ }^{18}$ Ibid.
} 
dan hasil penafsiran sebagai sebuah peziarahan tercermin dalam buku Teologi Perjanjian Lama yang ditulis oleh M.C. Barth-Frommel sebagai revisi Teologi Perjanjian Lama yang ditulis oleh mendiang suaminya, Ch. Barth. Bahan-bahan dan fokus perhatian dalam Teologi Perjanjian Lama yang ditulis oleh M.C. Barth-Frommel lebih mencerminkan keprihatinan yang dirasakan oleh gereja-gereja masa kini, seperti kerusakan alam, keadilan jender dan pluralitas agama-agama di Indonesia, yang tidak ada dalam Teologi Perjanjian Lama yang ditulis oleh Ch. Barth. ${ }^{19}$

\section{Kesimpulan}

Sebagai sebuah paradigma, ziarah mengingatkan kembali betapa pentingnya menghargai apa yang terjadi di masa lalu dalam proses penafsiran Alkitab. Sesuatu yang telah dihasilkan oleh gereja-gereja di masa lalu adalah warisan yang sangat berharga bagi gereja sekarang ini dalam melaksanakan tugas panggilannya. Menjadikan ziarah sebagai sebuah paradigma dalam menafsirkan Alkitab berarti juga memutuskan bahwa penafsiran Alkitab adalah bagian dari upaya gereja untuk mengenal jati dirinya di hadapan Allah, sekaligus menjadi agen perubahan bagi terciptanya kehidupan yang lebih baik di masa depan. Dan dalam mengupayakan perubahan-perubahan yang diharapkan, gereja tidak dapat berjalan sendiri. Gereja senantiasa ditantang untuk mampu bekerja sama dengan kelompok masyarakat lainnya sebagai sesama musafir di dunia ini. Dengan demikian gereja bersama kelompok masyarakat lainnya akan dapat berjalan bersama untuk menikmati perjumpaan dengan Allah.

\section{Kepustakaan}

Anderson, Janice C. \& Moore, Stephen D. "Introduction: The Lives of Mark", in Marks \& Method: New Approaches in Biblical Studies. Janice C. Anderson \& Stephen D. Moore, peny. Minneapolis: Fortress Press, 1992.

Barth, Ch. Theologia Perjanjian Lama 1, cetakan ke IV. Jakarta: BPK Gunung Mulia, 1993.

Barth, Ch. \& M.C. Barth-Frommel. Teologi Perjanjian Lama 1, edisi baru. Jakarta: BPK Gunung Mulia, 2008.

Eliade, M. The Encyclopedia of Religion, Vol 11. New York: Macmillan, 1987.

Fiorenza, Elisabeth S. But She Said: Feminist Practices of Biblical Interpretation. Boston, Massachusetts: Beacon Press, 1992.

\footnotetext{
${ }^{19}$ Bdk. Ch. Barth, Theologia Perjanjian Lama 1, cetakan ke IV (Jakarta: BPK Gunung Mulia, 1993), 26-87, dengan Barth, Ch. \& M.C. Barth-Frommel, Teologi Perjanjian Lama 1, edisi baru (Jakarta:
} BPK Gunung Mulia, 2008), 15-58. 
Fowler, Robert M. "Reader-Response Criticism: Figuring Mark's Reader", dalam Mark \& Method: New Approaches in Biblical Studies, peny. Janice C. Anderson \& Stephen D. Moore. Minneapolis: Fortress Press, 1993.

Gaventa, Baverly R., \& Hays, Richard B. Seeking Identity of Jesus: A Pilgrimage. Grand Rapids, MI: Wm. B. Eerdmans, 2008.

Groome, Thomas H. "Christian Education for Freedom: A Shared Praxis Approach", dalam Foundation of Religious Education, peny. Padraic O'Hare. New York: Paulist Press, 1978.

. Christian Religious Education. San Fransisco: Harper \& Row, 1980. . Sharing Faith. San Fransisco: Harper \& Row, 1991.

Komisi Kitab Suci dan Kepausan. Penafsiran Alkitab Dalam Gereja. terj. V. Indra Sanjaya Pr. Yogyakarta: Kanisius, 2003.

MacCormack, Sabine. "Loca Sancta: The Organization of Sacred Topography in Late Antiquity", in Blessings of Pilgrimage, peny. Robert Ousterhout. Urbana and Chicago: University of Illinois Press, 1990.

McDougall, Joy Ann. Pilgrimage of Love. Oxford: University Press, 2005.

Mulholland, M. Robert. Panggilan Ziarah: Bagaimana Mengembangkan Spiritualitas yang Holistik, terj. R. Herutomo. Yogyakarta: Yayasan Andi, 2002.

Plueddermann, James E. 'Do We Teach The Bible or Do We Teach Students?', dalam Christian Journal of Education X, no 1 (1989): 78.

Singgih, Emannuel Gerrit. “Apa dan Mengapa Exegese Naratif?”. GEMA: Exegese Narasi dalam Teori dan Praktek, no. 46 (1993): 5-26.

Yarchin, William. History of Biblical Interpretation: A Reader. Peabody, Massachusetts: Hendrickson Publishers, Inc.

Yong, Amos. Hospitality and the Other. New York: Orbis Books, 2008.

Zimmermann, Jens. Recovering Theological Hermenutics: An Incarnational-Trinitarian Theory of Interpretation. Grand Rapids, Michigan: Baker Academic, 2004. 